\title{
Impact of Five Cover Crop Green Manures and Actinovate on Fusarium Wilt of Watermelon
}

J. C. Himmelstein, University of Maryland, College Park 20742; J. E. Maul, United States Department of Agriculture-Agricultural Research Service, Beltsville, MD 20705; and K. L. Everts, University of Maryland, Lower Eastern Shore Research and Education Center, and University of Delaware, Georgetown 19947

\begin{abstract}
Himmelstein, J. C., Maul, J. E., and Everts, K. L. 2014. Impact of five cover crop green manures and Actinovate on Fusarium wilt of watermelon. Plant Dis. 98:965-972.

Triploid watermelon cultivars are grown on more than 2,023 ha in Maryland and in Delaware. Triploid watermelon cultivars have little host resistance to Fusarium wilt of watermelon (Fusarium oxysporum f. sp. niveum). The effects of four different fall-planted cover crops (Vicia villosa, Trifolium incarnatum, Secale cereale, and Brassica juncea) that were tilled in the spring as green manures, and bare ground, were evaluated alone and in combination with the biocontrol product Actinovate (Streptomyces lydicus) on Fusarium wilt severity and watermelon fruit yield and quality. Six field experiments were conducted over 3 years in Beltsville and Salisbury, MD and Georgetown, DE. Both V. villosa and T. incarnatum significantly suppressed Fusarium wilt of watermelon as much as $21 \%$ compared with watermelon in nonamended plots. However, no suppression of

Fusarium wilt occurred at low disease levels or where low cover crop biomass was present. In general, Beltsville, MD had lower disease levels than Salisbury, MD and Georgetown, DE. T. incarnatum was the only cover crop that yielded significantly more fruit than nonamended treatments (129\% more fruit per hectare) but only for one field trial. The Actinovate product either did not reduce Fusarium wilt or the magnitude of the reduction was nominal. Actinovate significantly reduced Fusarium wilt by $2 \%$ in 2009 and as much as $7 \%$ in 2010, and increased Fusarium wilt severity by $2.5 \%$ in 2011 . Actinovate significantly increased yield for one field trial but only when applied to nonamended or Secale cereal-amended plots. This is the first report of a reduction in Fusarium wilt following a T. incarnatum cover crop incorporated as a green manure.
\end{abstract}

Fusarium oxysporum f. sp. niveum W.C. Snyder \& H.N. Hansen is the cause of Fusarium wilt of watermelon (Citrullus lanatus (Thumb.) Matsum \& Nakai). Watermelon growers on the eastern shore of Maryland and in Delaware experience significant losses in yield due to the prevalence of Fusarium wilt in their fields (45). Losses can approach $100 \%$ if susceptible cultivars are planted in heavily infested fields (47). Yield loss is especially high in fields planted with triploid watermelon, which currently lacks resistance to Fusarium wilt (47). Consumer demand for triploid (seedless) watermelon has increased dramatically in recent years and triploid cultivars are now grown on more than $90 \%$ of watermelon production acreage. As a result, the need for management options for Fusarium wilt have also increased $(25,36)$.

Management options for Fusarium wilt of watermelon vary in effectiveness and cost. Grafting is an effective disease management tool; however, it requires high labor and seed costs and, therefore, is not currently practiced in the United States (17). Methyl bromide $(\mathrm{MeBr})$, a soil fumigant that was historically used to manage Fusarium wilt of watermelon (45), has been phased out due to its destructive effects on stratospheric ozone (12). Other soil fumigants such as metam sodium are available for management of Fusarium wilt but are generally not as effective as $\mathrm{MeBr}$ at reducing Fusarium wilt, are costly, and also have detrimental environmental effects (31). Alternative biological and cultural control methods are preferred.

Green manures are known to suppress several plant diseases $(20,21)$. Secale cereale residues decreased Fusarium root rot on beans by inhibiting chlamydospore germination of $F$. solani $\mathrm{f}$. $\mathrm{sp}$. phaseoli (21). Vicia villosa Roth (hairy vetch) cover crop amend-

Corresponding author: K. L. Everts, E-mail: keverts@umd.edu

Accepted for publication 31 January 2014.

http://dx.doi.org/10.1094/PDIS-06-13-0585-RE

(C) 2014 The American Phytopathological Society ments reduced inoculum density and chlamydospore viability of Thielaviopsis basicola, a pathogen of cotton seedlings $(1,4)$. In 2004, Zhou and Everts found that a V. villosa green manure decreased the incidence of Fusarium wilt on watermelon as much as 42 to $48 \%$ (45). In additional studies, a $V$. villosa cover crop was similarly effective against Fusarium wilt of watermelon, reducing it as much as $63 \%(16,43,46,47)$. Both $V$. villosa and T. incarnatum also increased watermelon fruit yield $(16,32)$. These yield increases were likely due to a decrease in Fusarium wilt and improved soil health. Despite these production benefits, the mechanism of $V$. villosa disease suppression of Fusarium wilt is still unknown.

There are a limited number of biocontrol products available for management of Fusarium wilt of watermelon and no one product is widely used $(22,23,39)$. Streptomyces spp. have been used as the active ingredient in disease management products (9). Actinovate AG (Natural Industries Inc.) is an Organic Materials Review Institute-approved biocontrol product whose active ingredient is Streptomyces lydicus strain WYEC 108. Actinovate is labeled for protection of watermelon from Fusarium wilt and is supposed to increase plant yields. Actinovate was effective at reducing disease in other pathosystems, such as Fusarium surface rot (Fusarium spp.) of postharvest sweet potato and dollar spot (Sclerotinia homoeocarpa) of warm- and cool-season grasses $(13,35)$. However, few studies have been conducted to evaluate Actinovate product effects on Fusarium wilt of watermelon under field conditions. Likewise, there are no studies that evaluate whether Actinovate in combination with a $V$. villosa cover crop will enhance disease suppression.

A combination of multiple biocontrol methods may achieve greater disease suppression than a single method. The dual application of an organic fertilizer amendment and antagonistic bacteria (Paenibacillus polymyxa SQR-1 and Bacillus subtilis SQR-5) significantly decreased Fusarium wilt of cucumber $(F$. oxysporum $\mathrm{f}$. sp. cucumerinum; 42). A compliment of wood chip amendments and Streptomyces spp. synergistically decreased Verticillium wilt (Verticillium dahliae) of potato (10). Actinovate was significantly 
more effective at reducing powdery mildew of summer squash (Cucurbita pepo) and cantaloupe (Cucumis melo) when applied with the fungicide Procure 480SC than when applied alone (41).

The objective of this study was to evaluate the efficacy of four cover crops-Vicia villosa, T. incarnatum, Brassica juncea, and Secale cereal - with and without an Actinovate biocontrol product on Fusarium wilt of field-grown triploid watermelon.

\section{Materials and Methods}

Experimental design. An experiment was conducted six times as randomized split plot block designs in three different locations over a period of 3 years (2009 to 2011; Table 1). Field locations included the United States Department of Agriculture (USDA) Henry A. Wallace Beltsville Agricultural Research Center (USDABARC) in Beltsville, MD (2009 and 2010); the University of Maryland Lower Eastern Shore Research and Education Center (UM-LESREC) in Salisbury (2009, 2010, and 2011); and the University of Delaware Carvel Research and Education Center (UDREC) in Georgetown (2011). The main plot treatments were cover crops and the subplots treatments were Actinovate and, in fields that were not infested, $F$. oxysporum $\mathrm{f}$. sp. niveum inoculation (Table 1). Noninfested fields were inoculated with $F$. oxysporum f. sp. niveum race 1 at USDA-BARC in 2009 and 2010 and at UM-LESREC in 2009. In these manually inoculated fields, the inoculum did not become adequately established and little to no disease was observed. Therefore, for other years and locations, trials were conducted in $F$. oxysporum f. sp. niveum-infested fields (Table 1).

At the USDA-BARC location, field soil was an amalgam of a Russett-Christiana and Downer-Hammonton complex of sandy loam. At UM-LESREC, field soil was Fort Mott loamy sand and, at UD-REC, Rosedale loamy sand. Cover crops were incorporated in the spring as a green manure. Cover crop treatments were $V$. villosa, $T$. incarnatum, $B$. juncea, and $S$. cereale but varied by year and location (Table 1).

Cover crops were seeded in late fall according to local seeding rates (Table 1). In 2011, due to low germination or winter kill the previous season, cover crops were overseeded at UM-LESREC and UD-REC, respectively, to ensure sufficient aboveground biomass (Table 1). Prior to planting, the seed of V. villosa and T. incarnatum were inoculated with a commercial Rhizobium sp., N-DURE (IN TX Microbials, LLC). At UM-LESREC in 2009, the cover crops were flattened with a culti-packer, mowed, and tilled. In all other locations, the cover crops were killed by a paraquat treatment (Gramoxone Extra 2.5SC, $1.2 \mathrm{~kg}$ a.i./ha, 1.75 liters/ha) in early spring (Table 1) and a tractor-mounted rototiller was used to disk the soil three times to a depth of approximately 15 to $20 \mathrm{~cm}$. Control plots were cultivated in the same manner.

In each plot, three $1-\mathrm{m}^{2}$ quadrats of aboveground plant biomass were collected, dried, and weighed prior to green manure incorporation. Biomass sample weights were used to estimate the amount of $\mathrm{N}$ the various cover crops contributed to their respective plots, and subsequent fertilization was based on these calculations. The fertilizer for each treatment was applied all at once, immediately prior to the laying of the black polyethylene mulch. All beds were formed by a bed shaper and a single drip irrigation tube was laid under black polyethylene mulch. Beds were laid on a $1.83-\mathrm{m}$ center in fields in 2009 and a 2.13-m center in 2010 and 2011.

Seed of 'Sugar Heart' watermelon were planted into trays in a potting mix (Sun Gro Redi-earth Plug and Seedling Mix; Sun Gro Horticulture). After 4 to 5 weeks of growth, watermelon seedlings were planted $0.91 \mathrm{~m}$ apart in each bed (Table 1). The pollinizer 'SP4,' which is resistant to Fusarium wilt race 1, was transplanted between every third seedless watermelon at all locations, except LESREC-UM in 2009 and USDA-BARC in 2010, when the diploid watermelon 'Royal Majesty' was used as a pollinizer. Insecticides and foliar fungicides were applied as needed according to extension recommendations for the mid-Atlantic. At USDABARC, two beehives were maintained centrally in the experimental site. On-farm bee hives at UD-REC and UM-LESREC were adjacent to the experimental fields. All fields were managed conventionally, except for the UM-LESREC field in 2009, which was managed with organic practices on organic-certified land.

The Natural Industries recommended rate of Actinovate AG foliar spray is $850.48 \mathrm{~g}$ of Actinovate AG per 946.25 liters of $\mathrm{H}_{2} \mathrm{O}$ per hectare. Therefore, $0.011 \mathrm{~g}$ of Actinovate AG per $12.2 \mathrm{ml}$ of $\mathrm{H}_{2} \mathrm{O}$ per $0.156-\mathrm{m}^{2}$ transplant tray was applied as a suspension to watermelon seedlings 1 to 2 weeks prior to transplanting (Table 1). Actinovate was also applied within the week following transplanting as a soil drench around the base of the plant at $255.14 \mathrm{~g}$ of

Table 1. Management and design of field experiments to evaluate tilled cover crop and Actinovate biocontrol application on Fusarium wilt severity (caused by Fusarium oxysporum f. sp. niveum [FON]) and watermelon yield for six different field trials in Maryland and in Delaware ${ }^{\mathrm{y}}$

\begin{tabular}{|c|c|c|c|c|c|c|}
\hline Parameters & $\begin{array}{c}\text { USDA-BARC } \\
2009\end{array}$ & $\begin{array}{c}\text { USDA-BARC } \\
2010\end{array}$ & $\begin{array}{c}\text { UM-LESREC } \\
2009\end{array}$ & $\begin{array}{c}\text { UM-LESREC } \\
2010\end{array}$ & $\begin{array}{c}\text { UM-LESREC } \\
2011\end{array}$ & $\begin{array}{l}\text { UD-REC } \\
2011\end{array}$ \\
\hline Main plot treatment & $\begin{array}{l}\text { V. villosa, } \\
\text { T. incarnatum, } \\
\text { S. cereale, } \\
\text { bare ground }\end{array}$ & $\begin{array}{l}\text { V. villosa, } \\
\text { T. incarnatum, } \\
\text { B. juncea, } \\
\text { S. cereale, } \\
\text { bare ground }\end{array}$ & $\begin{array}{l}\text { V. villosa, } \\
\text { S. cereale, } \\
\text { bare ground }\end{array}$ & $\begin{array}{l}\text { V. villosa, } \\
\text { T. incarnatum, } \\
\text { B. juncea, } \\
\text { S. cereale, } \\
\text { bare ground }\end{array}$ & $\begin{array}{l}\text { V. villosa, } \\
\text { T. incarnatum, } \\
\text { B. juncea, } \\
\text { S. cereale, } \\
\text { bare ground }\end{array}$ & $\begin{array}{l}\text { V. villosa, } \\
\text { T. incarnatum, } \\
\text { B. juncea, } \\
\text { S. cereale, } \\
\text { bare ground }\end{array}$ \\
\hline Subplot treatment & $\begin{array}{l}\text { FON, FON + } \\
\text { Actinovate, } \\
\text { No FON }\end{array}$ & $\begin{array}{l}\text { FON, FON + } \\
\text { Actinovate, } \\
\text { No FON }\end{array}$ & $\begin{array}{l}\text { FON, FON + } \\
\text { Actinovate, } \\
\text { No FON }\end{array}$ & $\begin{array}{l}\text { FON, FON + } \\
\text { Actinovate }\end{array}$ & $\begin{array}{l}\text { FON, FON + } \\
\text { Actinovate }\end{array}$ & $\begin{array}{l}\text { FON, FON + } \\
\text { Actinovate }\end{array}$ \\
\hline $\begin{array}{l}\text { Cover crop seeding } \\
\text { rates }(\mathrm{kg} / \mathrm{ha})\end{array}$ & $\begin{array}{l}\text { V. villosa } 44.83, \\
\text { T. incarnatum } \\
28.02, \\
\text { S. cereale } 134.50\end{array}$ & $\begin{array}{l}\text { V. villosa } 44.83 \text {, } \\
\text { T. incarnatum } \\
28.02, \\
\text { S. cereale } 134.50 \text {, } \\
\text { B. juncea } 6.73\end{array}$ & $\begin{array}{l}\text { V. villosa } 50.44, \\
\text { S. cereale } 134.50\end{array}$ & $\begin{array}{l}\text { V. villosa } 50.44 \text {, } \\
\text { T. incarnatum } \\
11.21 \text {, } \\
\text { S. cereale } 125.54 \text {, } \\
\text { B. juncea } 11.21\end{array}$ & $\begin{array}{l}\text { V. villosa } 50.44 \text {, } \\
\text { T. incarnatum } \\
11.21 \text {, } \\
\text { S. cereale } 125.54 \text {, } \\
\text { B. juncea } 11.21\end{array}$ & $\begin{array}{l}\text { V. villosa } 50.44 \text {, } \\
\text { T. incarnatum } \\
11.21 \text {, } \\
\text { S. cereale } 125.54 \text {, } \\
\text { B. juncea } 11.21\end{array}$ \\
\hline $\begin{array}{l}\text { Cover crop seeding } \\
\text { dates }\end{array}$ & $9 / 24 / 2008$ & $9 / 22 / 2009$ & $10 / 16 / 2008$ & $9 / 25 / 2009$ & $\begin{array}{l}10 / 15 / 2010 \\
3 / 9 / 2011^{z}\end{array}$ & $\begin{array}{c}10 / 25 / 2010 \\
3 / 15 / 2011\end{array}$ \\
\hline Cover crop tillage & $5 / 23 / 2009$ & $5 / 23 / 2010$ & $5 / 15 / 2009$ & $5 / 24 / 2010$ & $5 / 19 / 2011$ & $5 / 25 / 2011$ \\
\hline $\begin{array}{l}\text { Dates of Actinovate } \\
\text { applications }\end{array}$ & $\begin{array}{l}\text { Foliar 6/03/2009; } \\
\text { Soil drench } \\
\text { 6/29/2009 }\end{array}$ & $\begin{array}{l}\text { Foliar 6/16/2010; } \\
\text { Soil drench } \\
6 / 29 / 2010\end{array}$ & $\begin{array}{l}\text { Foliar 6/02/2009; } \\
\text { Soil drench } \\
\text { 6/29/2009 }\end{array}$ & $\begin{array}{l}\text { Foliar 6/08/2010; } \\
\text { Soil drench } \\
6 / 15 / 2010\end{array}$ & $\begin{array}{l}\text { Foliar 5/20/2011; } \\
\text { Soil drench } \\
6 / 03 / 2011\end{array}$ & $\begin{array}{l}\text { Foliar 5/26/2011; } \\
\text { Soil drench } \\
6 / 07 / 2011\end{array}$ \\
\hline $\begin{array}{l}\text { Watermelon } \\
\text { transplant date }\end{array}$ & $6 / 17 / 2009$ & $6 / 18 / 2010$ & $6 / 19 / 2009$ & $6 / 12 / 2010$ & 6/03/2011 & 6/07/2011 \\
\hline
\end{tabular}

y USDA-BARC = United States Department of Agriculture Beltsville Agricultural Research Center located in Beltsville, MD; UM-LESREC = University of Maryland Lower Eastern Shore Research and Education Center located in Salisbury; and UD-REC = University of Delaware's Carvel Research and Education Center, located in Georgetown. Cover crops were Vicia villosa, Trifolium incarnatum, Secale cereale, and Brassica juncea. Actinovate AG is a biocontrol product (Natural Industries Inc.) which is labeled for management of Fusarium wilt of watermelon.

${ }^{\mathrm{z}}$ In 2011, cover crops were overseeded in the early spring to ensure that plots had sufficient cover crop biomass. 
Actinovate AG per 378.5 liters of $\mathrm{H}_{2} \mathrm{O}$ per $4,046.86 \mathrm{~m}^{2}$; approximately $0.115 \mathrm{~g}$ per $172 \mathrm{ml}$ of $\mathrm{H}_{2} \mathrm{O}$ per $1.89 \mathrm{~m}^{2}$ per plant.

A race 1 isolate (F-030-1) of $F$. oxysporum $\mathrm{f}$. sp. niveum, which was acquired from a wilted watermelon plant in Wicomico, MD in a previous study (44), was used for disease inoculations. Strains were maintained in a mixture of sandy soil and perlite $(1: 2, \mathrm{wt} / \mathrm{wt})$ at $4^{\circ} \mathrm{C}$. Inoculum was prepared by transferring agar pieces containing $F$. oxysporum f. sp. niveum (F-030-1) mycelium and spores grown on Komadas media (19) into a liquid mineral salts medium (27). Each 2-liter flask received approximately half of an 80-mm plate. The culture was incubated on an orbital shaker at $128 \mathrm{rpm}$ at room temperature for approximately 2 weeks before filtering through eight layers of cheesecloth. A Spencer hemacytometer was used to adjust the spore suspension to the desired concentration.

In 2009 at both USDA-BARC and UM-LESREC, seedlings were inoculated immediately after transplanting by pipetting $6 \mathrm{ml}$ of $F$. oxysporum f. sp. niveum inoculum at a concentration of 2.45 $\times 10^{6} \mathrm{CFU}$ (primarily micronidia) per milliliter into a hole (roughly $3 \mathrm{~cm}$ in diameter and $8 \mathrm{~cm}$ deep) $7 \mathrm{~cm}$ away from the crown of the watermelon plant (45). In 2010 at USDA-BARC, the F. oxysporum $\mathrm{f}$. sp. niveum inoculation method was modified to increase disease incidence. Two days after cover crop incorporation and a week prior to the laying of black plastic, $60 \mathrm{ml}$ of $F$. oxysporum $\mathrm{f}$. sp. niveum inoculum at $2.85 \times 10^{8} \mathrm{CFU} / \mathrm{ml}$ was mixed into 3.79 liters of $\mathrm{H}_{2} \mathrm{O}$ and evenly banded across the center of each $36.92-\mathrm{m}^{2}$ bed with a watering can. A second application of $11 \mathrm{ml}$ of $F$. oxysporum f. sp. niveum inoculum at a concentration of 2.33 $\times 10^{6} \mathrm{CFU} / \mathrm{ml}$ was pipetted next to each watermelon plant using the same method employed in 2009. Inoculum was applied at concentrations that were previously calculated to result in approximately $60 \%$ wilt on a highly susceptible cultivar (44).

Fusarium wilt ratings. Watermelon were planted $0.91 \mathrm{~m}$ apart in a bed but the total number of watermelon planted per treatment bed varied depending on year and location ( $n=10$ to 16 watermelon plants/treatment bed). Wilt severity was rated as the percentage of wilted watermelon foliage for each plant and averaged for each bed (20). Fusarium wilt severity was evaluated weekly after transplanting in 2009. In 2009, additional symptoms of stunting and chlorosis were present and included in the wilt rating, as follows. For 2009 only, if a watermelon plant was chlorotic, the wilt rating was increased by $10 \%$ for that plant and, if a watermelon was stunted, the wilt rating was increased by $25 \%$. In 2010, Fusarium wilt severity was measured three times at UM-LESREC and once at USDA-BARC. In 2011, Fusarium wilt severity was evaluated weekly following transplanting. The area under the disease progress curve (AUDPC) was calculated for each field trial except at USDA-BARC in 2010 because only one wilt rating was taken. The AUDPC was calculated as AUDPC $=\Sigma\left[\left(y_{i}+y_{i+1}\right) / 2 \times\right.$ $\left.\left(t_{i+1}-t_{i}\right)\right]$. Stems of wilted watermelon plants were plated on Komadas media to verify the presence of $F$. oxysporum f. sp. niveum (19).

Plant vigor and yield. In 2010, watermelon vine length was measured approximately 3 weeks following transplanting at both locations. In 2011, vines were measured twice at UM-LESREC: once 7 days after transplanting and again the following week. At UD-REC, vines were measured three times at weekly intervals beginning 7 days after transplanting.

All fruit were individually weighed and counted at harvest, percent Brix (sugar content) was assessed for three watermelon fruit per bed ( $n=144$ to 180 fruit sampled/field) with a hand held refractometer, and the numbers of sunburned fruit were counted. Treatment effects were evaluated for marketable watermelon yield and total watermelon weight. Marketable-sized fruit were defined as watermelon that weighed $>3.18 \mathrm{~kg}$.

Streptomyces lydicus in the rhizosphere. In 2010, directly after fruit harvest, seminal watermelon roots from each plot in four of the replicate blocks at UM-LESREC and USDA-BARC ( $n=40$ to 60 , respectively) were plated on arginine-glycerol-salt agar to observe any growth of Streptomyces spp. from the roots, to determine whether Streptomyces lydicus successfully colonized the watermelon roots (7). Because no $S$. lydicus colonies were observed in 2010, sampling was instead done 2 weeks after watermelon were transplanted to the field in 2011 at both UM-LESREC and UDREC. Seminal roots of destructively harvested watermelon plants, one for each plot $(n=60)$, were cut into three $3-\mathrm{cm}$ root sections, put into test tubes with $5 \mathrm{ml}$ of sterile distilled water, soaked for 5

Table 2. Variance analysis ( $P$ values) for the effects of cover crop and Actinovate AG application main effects on watermelon Fusarium wilt severity and the area under the disease progress curve (AUDPC) in field experiments conducted at the University of Maryland's Lower Eastern Shore Research and Education Center (UM-LESREC), the United States Department of Agriculture at the Beltsville Agricultural Research Center (USDA-BARC), and University of Delaware's Carvel Research and Education Center (UD-REC) in 2009, 2010, and 2011

\begin{tabular}{|c|c|c|c|c|c|c|c|c|c|}
\hline Location, year ${ }^{\mathrm{z}}$ & Week 1 & Week 2 & Week 3 & Week 4 & Week 5 & Week 6 & Week 7 & Week 8 & AUDPC \\
\hline \multicolumn{10}{|l|}{2009} \\
\hline \multicolumn{10}{|l|}{ UM-LESREC } \\
\hline Cover Crop & - & 0.0016 & 0.6832 & 0.6743 & 0.8041 & 0.4853 & 0.5593 & - & 0.6459 \\
\hline Actinovate & - & 0.7363 & 0.1392 & 0.1396 & 0.3596 & 0.0096 & 0.7203 & - & 0.1533 \\
\hline \multicolumn{10}{|l|}{ USDA-BARC } \\
\hline Cover Crop & - & - & 0.3475 & 0.7066 & 0.4363 & 0.5578 & 0.3569 & - & 0.3858 \\
\hline Actinovate & - & - & 0.9085 & 0.5346 & 0.3829 & 0.4297 & 1.0000 & - & 0.8924 \\
\hline \multicolumn{10}{|l|}{2010} \\
\hline \multicolumn{10}{|l|}{ UM-LESREC } \\
\hline Cover Crop & 0.5496 & - & - & 0.1619 & - & 0.0887 & - & - & 0.2024 \\
\hline Actinovate & 0.0670 & - & - & 0.0379 & - & 0.0603 & - & - & 0.0373 \\
\hline \multicolumn{10}{|l|}{ USDA-BARC } \\
\hline Cover Crop & - & - & - & - & - & - & - & 0.1386 & - \\
\hline Actinovate & - & - & - & - & - & - & - & 0.3707 & - \\
\hline \multicolumn{10}{|l|}{2011} \\
\hline \multicolumn{10}{|l|}{ UM-LESREC } \\
\hline Cover Crop & 0.4118 & 0.1152 & 0.1445 & 0.0013 & 0.0056 & $<0.0001$ & 0.0458 & - & $<0.0001$ \\
\hline Actinovate & 0.0924 & 0.7092 & 0.6713 & 0.9771 & 0.5115 & 0.6459 & 0.5030 & - & 0.5247 \\
\hline \multicolumn{10}{|l|}{ UD-REC } \\
\hline Cover Crop & 0.3888 & 0.4779 & 0.2418 & 0.4201 & 0.1641 & 0.0175 & 0.0535 & - & 0.0251 \\
\hline Actinovate & 0.1319 & 0.1898 & 0.0206 & 0.7908 & 0.6214 & 0.6861 & 0.3333 & - & 0.8020 \\
\hline
\end{tabular}

${ }^{y}$ Number of weeks after watermelons were transplanted to the field; - indicates that the measurement was not taken for that date and location or, for USDABARC in 2010, that no wilt was observed.

${ }^{\mathrm{z}}$ Cover crop seeding rates at UM-LESREC and UD-REC were Vicia villosa at $50.44 \mathrm{~kg} / \mathrm{ha}$, Trifolium incarnatum at $11.21 \mathrm{~kg} / \mathrm{ha}$, Secale cereale at 125.54 $134.50 \mathrm{~kg} / \mathrm{ha}$, and Brassica juncea at $11.21 \mathrm{~kg} / \mathrm{ha}$; and, at USDA-BARC, the seeding rates were V. villosa at $44.83 \mathrm{~kg} / \mathrm{ha}, T$. incarnatum at $28.02 \mathrm{~kg} / \mathrm{ha}, S$. cereale at $134.50 \mathrm{~kg} / \mathrm{ha}$, and $B$. juncea at $6.73 \mathrm{~kg} / \mathrm{ha}$. Actinovate AG's active ingredient is Streptomyces lydicus and is produced by Natural Industries. Actinovate was applied as a foliar spray to watermelon plants 2 weeks after seeding at a rate of $0.011 \mathrm{~g}$ per $12.2 \mathrm{ml}_{\text {of }} \mathrm{H}_{2} \mathrm{O}$ per $0.156-\mathrm{m}^{2}$ transplant tray and again a week prior to transplanting to the field as a soil drench around the base of the plant at $0.115 \mathrm{~g}$ per $172 \mathrm{ml}_{\text {of }} \mathrm{H}_{2} \mathrm{O}$ per $1.89 \mathrm{~m}^{2}$ per plant. 
min, and vortexed. The root segments were removed and the resulting soil-water mixture was serially diluted onto sporulation ager amended with nyastatin, carbenicillin, and cycloheximide and casein agar to observe if Streptomyces spp. were present in the soil rhizosphere (40).

Nutrient analyses. Treatment effects on the nutrient content of soil, dried cover crop foliage, and dried watermelon foliage were analyzed in 2011 to determine whether nutritional differences impacted disease suppression (29). In 2011, three 6-in. $(15 \mathrm{~cm})$ soil cores were collected from each treatment plot following tillage (25 May at UD-REC and 20 June at UM-LESREC) and analyzed at the University of Delaware's soil testing lab for $\mathrm{pH}$; buffer $\mathrm{pH}$; percent organic matter; $\mathrm{P}, \mathrm{K}, \mathrm{Ca}, \mathrm{Mg}, \mathrm{Mn}, \mathrm{Zn}, \mathrm{Cu}, \mathrm{Fe}, \mathrm{B}, \mathrm{S}$, and $\mathrm{Al}$ in milligrams per kilogram; CEC (meq/100 g); percent base saturation; and $\mathrm{P}$ saturation ratio. Cover crop biomass was collected three times from $2 \mathrm{~m}^{2}$ in each plot, at both locations, approximately a week prior to soil incorporation.

Statistical analyses. Data were analyzed using the MIXED procedure with the Statistical Analysis System (version 9.2; SAS Institute, Cary, NC), which integrates random effects in the statistical model and performs covariance structure modeling (24). Treatment means were separated using a Fisher's protected least significant difference test at $P \leq 0.05$. When disease was low, the proportional wilt data was usually not normally distributed. However, because of the large sample size $(n>30)$, this data was considered robust enough to be analyzed without transformation (30). This is supported by the Central Limit Theorem, which states that the sample mean of a population same size of $n>30$ will converge to a standard normal distribution (3).

\section{Results}

Fusarium wilt severity. Fusarium wilt severity varied by location and year. Fusarium wilt severity was low at USDA-BARC while it was high in fields on the eastern shore of Maryland and in Delaware, and significant differences in disease suppression across locations were observed.

Cover crop biomass also varied across locations and, at UMLESREC in 2010, heavy winter snowfall reduced cover crop biomass in many of the plots. Therefore, wilt severity data from the UM-LESREC 2010 field season are excluded from these results. In 2011 at UD-REC and UM-LESREC, cover crops were overseeded in the early spring to ensure sufficient biomass coverage, the weather was moderate, and watermelon crops were planted in fields with soil conditions conducive to Fusarium wilt and which already had high levels of $F$. oxysporum $\mathrm{f}$. sp. niveum (Table 1 ).

There was low disease pressure at UM-LESREC in 2009, which resulted in no or very low wilt severity (less than a percent difference) among treatments (Tables 2 and 3). V. villosa and T. incarnatum green manures suppressed Fusarium wilt of watermelon at both UM-LESREC and UD-REC in 2011 (Table 3). For the majority of the watermelon growing season, watermelon plants in $V$. villosa-amended plots and T. incarnatum-amended plots had significantly less disease than plants in nonamended plots or in plots amended with any other cover crop treatment at UM-LESREC in

Table 3. Percent watermelon wilt severity following tilled cover crop or bare ground at the University of Maryland's Lower Eastern Shore Research and Education Center (UM-LESREC), the United States Department of Agriculture Beltsville Agricultural Research Center (USDA-BARC), and University of Delaware's Carvel Research and Education Center (UD-REC) in 2009, 2010, and 2011

\begin{tabular}{|c|c|c|c|c|c|c|c|c|c|}
\hline \multirow[b]{2}{*}{ Location, year, crop ${ }^{z}$} & \multicolumn{9}{|c|}{ Weeks after transplanting ${ }^{y}$} \\
\hline & 1 & 2 & 3 & 4 & 5 & 6 & 7 & 8 & AUDPC \\
\hline \multicolumn{10}{|l|}{ USDA-BARC, 2009} \\
\hline V. villosa & - & - & $1.30 \mathrm{a}$ & $0.00 \mathrm{a}$ & $0.42 \mathrm{a}$ & $0.42 \mathrm{a}$ & $0.00 \mathrm{a}$ & - & $1.50 \mathrm{a}$ \\
\hline T. incarnatum & - & - & $0.42 \mathrm{a}$ & $0.42 \mathrm{a}$ & $0.00 \mathrm{a}$ & $0.42 \mathrm{a}$ & $0.42 \mathrm{a}$ & _- & $1.20 \mathrm{a}$ \\
\hline S. cereale & - & - & $0.71 \mathrm{a}$ & $0.21 \mathrm{a}$ & $0.00 \mathrm{a}$ & $1.25 \mathrm{a}$ & $0.83 \mathrm{a}$ & - & $2.22 \mathrm{a}$ \\
\hline Bare ground & - & - & $2.92 \mathrm{a}$ & $0.63 \mathrm{a}$ & $0.00 \mathrm{a}$ & $0.21 \mathrm{a}$ & $0.00 \mathrm{a}$ & - & $4.17 \mathrm{a}$ \\
\hline$P>F$ & $\ldots$ & $\ldots$ & 0.3475 & 0.7066 & 0.4363 & 0.5578 & 0.3569 & $\ldots$ & 0.3858 \\
\hline \multicolumn{10}{|l|}{ UM-LESREC, 2009} \\
\hline V. villosa & - & $0.97 \mathrm{~b}$ & $0.92 \mathrm{a}$ & $0.053 \mathrm{a}$ & $1.10 \mathrm{a}$ & $0.28 \mathrm{a}$ & $1.40 \mathrm{a}$ & - & $3.50 \mathrm{a}$ \\
\hline S. cereale & - & $0.49 \mathrm{a}$ & $6.20 \mathrm{a}$ & $0.38 \mathrm{a}$ & $1.10 \mathrm{a}$ & $1.10 \mathrm{a}$ & $1.70 \mathrm{a}$ & - & $12.10 \mathrm{a}$ \\
\hline Bare ground & - & $0.97 \mathrm{~b}$ & $6.80 \mathrm{a}$ & $0.40 \mathrm{a}$ & $0.56 \mathrm{a}$ & $0.56 \mathrm{a}$ & $2.50 \mathrm{a}$ & _- & $10.00 \mathrm{a}$ \\
\hline$P>F$ & $\ldots$ & 0.0016 & 0.6832 & 0.6743 & 0.8041 & 0.4853 & 0.5593 & $\ldots$ & 0.6459 \\
\hline \multicolumn{10}{|l|}{ USDA-BARC, 2010} \\
\hline V. villosa & - & - & - & - & - & - & - & $12.12 \mathrm{a}$ & - \\
\hline T. incarnatum & - & - & - & - & - & - & - & $13.82 \mathrm{a}$ & - \\
\hline S. cereale & - & - & - & - & - & _- & - & $18.50 \mathrm{a}$ & - \\
\hline B. juncea & - & - & - & - & - & - & - & $26.91 \mathrm{a}$ & - \\
\hline Bare ground & - & - & - & - & - & - & - & $20.64 \mathrm{a}$ & - \\
\hline$P>F$ & $\ldots$ & $\ldots$ & $\ldots$ & $\ldots$ & $\ldots$ & $\ldots$ & $\ldots$ & 0.1386 & \\
\hline \multicolumn{10}{|l|}{ UM-LESREC, 2011} \\
\hline V. villosa & $0.64 \mathrm{a}$ & $5.63 \mathrm{a}$ & $8.71 \mathrm{a}$ & $27.58 \mathrm{~b}$ & $41.86 \mathrm{~b}$ & $40.68 \mathrm{~b}$ & $35.90 \mathrm{~b}$ & - & $124.55 \mathrm{~b}$ \\
\hline T. incarnatum & $0.00 \mathrm{a}$ & $2.08 \mathrm{a}$ & $4.92 \mathrm{a}$ & $31.36 \mathrm{~b}$ & $47.20 \mathrm{~b}$ & $31.14 \mathrm{~b}$ & $43.48 \mathrm{ab}$ & - & $119.16 \mathrm{~b}$ \\
\hline S. cereale & $1.12 \mathrm{a}$ & $4.38 \mathrm{a}$ & $13.83 \mathrm{a}$ & $46.44 \mathrm{a}$ & $60.95 \mathrm{a}$ & $54.81 \mathrm{a}$ & $51.02 \mathrm{a}$ & - & $189.43 \mathrm{a}$ \\
\hline B. juncea & $0.32 \mathrm{a}$ & $6.25 \mathrm{a}$ & $14.48 \mathrm{a}$ & $48.56 \mathrm{a}$ & $66.10 \mathrm{a}$ & $56.97 \mathrm{a}$ & $54.62 \mathrm{a}$ & - & $196.66 \mathrm{a}$ \\
\hline Bare ground & $1.44 \mathrm{a}$ & $6.46 \mathrm{a}$ & $7.01 \mathrm{a}$ & $48.26 \mathrm{a}$ & $57.31 \mathrm{a}$ & $52.05 \mathrm{a}$ & $52.61 \mathrm{a}$ & _- & $184.09 \mathrm{a}$ \\
\hline$P>\mathrm{F}$ & 0.4180 & 0.1152 & 0.1445 & 0.0056 & 0.0056 & $<0.0001$ & 0.0458 & & $<0.0001$ \\
\hline \multicolumn{10}{|l|}{ UD-REC, 2011} \\
\hline V. villosa & $0.60 \mathrm{a}$ & $1.49 \mathrm{a}$ & $14.00 \mathrm{a}$ & $13.74 \mathrm{a}$ & $11.50 \mathrm{a}$ & $6.68 \mathrm{c}$ & $12.12 \mathrm{a}$ & - & $56.27 \mathrm{~b}$ \\
\hline T. incarnatum & $0.60 \mathrm{a}$ & $1.49 \mathrm{a}$ & $16.03 \mathrm{a}$ & $15.97 \mathrm{a}$ & $15.19 \mathrm{a}$ & $9.49 \mathrm{bc}$ & $15.61 \mathrm{a}$ & - & $68.04 \mathrm{ab}$ \\
\hline S. cereale & $1.79 \mathrm{a}$ & $8.93 \mathrm{a}$ & $15.18 \mathrm{a}$ & $16.42 \mathrm{a}$ & $13.53 \mathrm{a}$ & $12.91 \mathrm{ab}$ & $19.35 \mathrm{a}$ & - & $72.91 \mathrm{ab}$ \\
\hline B. juncea & $3.57 \mathrm{a}$ & $13.39 \mathrm{a}$ & $16.69 \mathrm{a}$ & $18.16 \mathrm{a}$ & $16.34 \mathrm{a}$ & $12.98 \mathrm{ab}$ & $22.46 \mathrm{a}$ & - & $81.82 \mathrm{a}$ \\
\hline Bare ground & $2.38 \mathrm{a}$ & $8.93 \mathrm{a}$ & $18.18 \mathrm{a}$ & $19.97 \mathrm{a}$ & $17.34 \mathrm{a}$ & $15.19 \mathrm{a}$ & $23.53 \mathrm{a}$ & _- & $84.57 \mathrm{a}$ \\
\hline$P>F$ & 0.3888 & 0.4779 & 0.2418 & 0.4201 & 0.1641 & 0.0175 & 0.0535 & $\ldots$ & 0.0251 \\
\hline
\end{tabular}

${ }^{y}$ Means in a column followed by the same letter are not significantly different at $\alpha=0.05$ according to Fisher's protected least significant difference test. Statistical analysis was conducted using the Statistical Analysis System MIXED procedure; - indicates that the measurement was not taken for that date and location or, for USDA-BARC in 2010, that no wilt was observed; AUDPC = area under the disease progress curve.

${ }^{\mathrm{z}}$ Due to low levels of aboveground cover crop, biomass results from UM-LESREC 2010 are omitted. Cover crop seeding rates at UM-LESREC and UDREC were Vicia villosa at $50.44 \mathrm{~kg} / \mathrm{ha}$, Trifolium incarnatum at $11.21 \mathrm{~kg} / \mathrm{ha}$, Secale cereale at $125.54-134.50 \mathrm{~kg} / \mathrm{ha}$, and Brassica juncea at $11.21 \mathrm{~kg} / \mathrm{ha}$; and, at USDA-BARC, the seeding rates were V. villosa at $44.83 \mathrm{~kg} / \mathrm{ha}$, T. incarnatum at $28.02 \mathrm{~kg} / \mathrm{ha}$, S. cereale at $134.50 \mathrm{~kg} / \mathrm{ha}$, and B. juncea at 6.73 $\mathrm{kg} / \mathrm{ha}$. 
2011 (Table 3). Watermelon in V. villosa and T. incarnatumamended plots at UM-LESREC in 2011 also had a lower AUDPC (124.55 and 119.16, respectively) compared with watermelon planted in B. juncea-amended (196.66) or bare ground (184.09) plots (Table 3). Fusarium wilt severity of watermelon in B. junceaamended plots was consistently the highest or second highest numerically, although never significantly higher than on watermelon in nonamended or Secale cereal-amended plots (Table 3).

Both leguminous cover crops also suppressed Fusarium wilt at UD-REC in 2011. However, T. incarnatum did not achieve the same magnitude of disease suppression as $V$. villosa. Six weeks after transplanting to the field, the watermelon grown in $V$. villosaamended plots had significantly less disease than watermelon in any other treatment plots except for that of $T$. incarnatum-amended plots. Watermelon in T. incarnatum plots also had significantly less Fusarium wilt than plants in bare ground plots (Table 3). Watermelon wilt severity was similarly lowest in V. villosa- and $T$. incarnatum-amended plots the following week, although the $P$ value was marginally significant at 0.0535 (Table 3). The AUDPC of watermelon in $V$. villosa-amended plots was significantly less (56.27) than watermelon in B. juncea- (81.82) and bare ground- (84.57) treated plots (Table 3 ). Cover crop treatments did not significantly influence Fusarium wilt at USDA-BARC, where disease was low, but the same trend in $V$. villosa and T. incarnatum disease suppression was still numerically apparent in 2009 and 2010 (Table 3).

Actinovate treatments nominally reduced Fusarium wilt for two field trials and increased Fusarium wilt for one field trial. Six weeks after transplanting, at UM-LESREC in 2009, watermelon treated with Actinovate had $1.94 \%$ less Fusarium wilt than watermelon in untreated plots (Table 4). At UM-LESREC in 2010, the AUDPC and Fusarium wilt severity measured 4 weeks after transplanting was $7.07 \%$ lower for watermelon in Actinovatetreated plots than for watermelon in control plots. In contrast, Actinovate biocontrol applications increased Fusarium wilt severity $2.45 \%$ for the wilt reading taken 3 weeks after transplanting at UD-REC in 2011 (Table 4). Ultimately, Actinovate treatment effects were minimal and inconsistent. For all field trials, there were no significant interactions between the cover crop and Actinovate biocontrol treatments for their effects on Fusarium wilt severity $(P \geq 0.1340)$.

Plant vigor and yield. Significant cover crop treatment effects on marketable watermelon yield were only observed at UMLESREC in 2011, where T. incarnatum-amended plots had marketable watermelon yield that was higher $\left(14.67 \times 10^{2}\right.$ to $20.68 \times$ $10^{2}$ more fruit per hectare) than that of all other amended or nonamended plots (Table 5).
There was a significant Actinovate-cover crop treatment interaction for marketable watermelon number for only one field trial. Beds amended with $S$. cereale or bare ground and treated with Actinovate had significantly higher marketable yield compared with their respective untreated or uninoculated beds at USDABARC in $2009(P=0.0109)$. The only other field trial where Actinovate demonstrated significant positive effects on marketable watermelon yield was at UM-LESREC in 2011, when Actinovate significantly increased marketable watermelon yield (933 more fruit per hectare) compared with beds that were not treated with Actinovate (Table 5).

No individual cover crop or Actinovate treatment affected marketable watermelon weight for any field trial $(P \geq 0.1314)$. In addition, no cover crop or Actinovate treatment effects were seen in more than one field trial for sugar content, watermelon vine length, or the number of sunburned watermelon (data not shown).

Streptomyces lydicus isolation. Streptomyces lydicus was never isolated from watermelon roots in any of the sampled locations (UM-LESREC and USDA-BARC in 2010 and UM-LESREC and UD-REC in 2011). Therefore, the establishment of S. lydicus was never confirmed.

Nutrient analyses. Differences in cover crop and soil nutrient concentrations were not consistent across field locations and there were no obvious trends that linked these variations to Fusarium wilt disease suppression (data not shown). No other significant differences were seen for the soil analysis conducted at UMLESREC and UD-REC.

\section{Discussion}

$V$. villosa and T. incarnatum reduced Fusarium wilt of watermelon at UD-REC and UM-LESREC in 2011. The ability of a $V$. villosa cover crop to suppress Fusarium wilt of watermelon has been observed in previous studies done on the eastern shore of Maryland (44-46); however, no previous studies have reported the disease suppressive effects of a $T$. incarnatum green manure on Fusarium wilt of watermelon or, to our knowledge, for any other plant disease.

The efficacy of $T$. incarnatum was tested in these trials because $V$. villosa and $T$. incarnatum cover crops have similar growth characteristics and confer comparable soil-improving benefits. Both cover crops rapidly produce large amounts of aboveground biomass in early spring, serving as effective weed suppressants (2). Their low $\mathrm{C}: \mathrm{N}$ ratios result in a fast, extensive breakdown of foliage, stimulating substantial soil microbial activity. They are both flowering legumes which encourage beneficial insects and fix a corresponding amount of nitrogen per acre (2).

Table 4. Effect of Actinovate AG on percent Fusarium wilt severity of watermelon, caused by the pathogen Fusarium oxysporum f. sp. niveum (FON), at the University of Maryland's Lower Eastern Shore Research and Education Center (UM-LESREC) in 2009 and 2010 and the University of Delaware's Carvel Research and Education Center (UD-REC) in 2011

\begin{tabular}{|c|c|c|c|c|c|c|c|c|c|}
\hline \multirow[b]{2}{*}{ Location, year, treatment } & \multicolumn{9}{|c|}{ Week after transplanting ${ }^{\mathrm{z}}$} \\
\hline & 1 & 2 & 3 & 4 & 5 & 6 & 7 & 8 & AUDPC \\
\hline \multicolumn{10}{|l|}{ UM-LESREC, 2009} \\
\hline Nontreated & - & $2.25 \mathrm{a}$ & $0.28 \mathrm{a}$ & $0.01 \mathrm{a}$ & $0.83 \mathrm{a}$ & $0.00 \mathrm{~b}$ & $2.22 \mathrm{a}$ & - & $3.36 \mathrm{a}$ \\
\hline FON & - & $1.94 \mathrm{a}$ & $13.25 \mathrm{a}$ & $0.84 \mathrm{a}$ & $1.67 \mathrm{a}$ & $1.94 \mathrm{a}$ & $1.39 \mathrm{a}$ & - & $19.37 \mathrm{a}$ \\
\hline FON + Actinovate & - & $2.64 \mathrm{a}$ & $0.40 \mathrm{a}$ & $0.02 \mathrm{a}$ & $0.28 \mathrm{a}$ & $0.00 \mathrm{~b}$ & $1.94 \mathrm{a}$ & - & $2.99 \mathrm{a}$ \\
\hline$P>F$ & $\ldots$ & 0.7363 & 0.1392 & 0.1396 & 0.3596 & 0.0096 & 0.7203 & $\ldots$ & 0.1533 \\
\hline \multicolumn{10}{|l|}{ UM-LESREC, 2010} \\
\hline FON & $4.88 \mathrm{a}$ & - & - & $9.75 \mathrm{a}$ & - & $10.31 \mathrm{a}$ & - & - & $28.07 \mathrm{a}$ \\
\hline FON+ Actinovate & $2.44 \mathrm{a}$ & - & - & $2.68 \mathrm{~b}$ & - & $3.81 \mathrm{a}$ & - & - & $9.95 \mathrm{~b}$ \\
\hline$P>F$ & 0.067 & $\ldots$ & $\ldots$ & 0.0379 & $\ldots$ & 0.0603 & $\ldots$ & $\ldots$ & 0.0373 \\
\hline \multicolumn{10}{|l|}{ UD-REC, 2011} \\
\hline FON & $2.62 \mathrm{a}$ & $1.01 \mathrm{a}$ & $14.80 \mathrm{~b}$ & $16.26 \mathrm{a}$ & $15.12 \mathrm{a}$ & $11.17 \mathrm{a}$ & $19.46 \mathrm{a}$ & - & $72.09 \mathrm{a}$ \\
\hline FON + Actinovate & $0.95 \mathrm{a}$ & $0.36 \mathrm{a}$ & $17.25 \mathrm{a}$ & $16.64 \mathrm{a}$ & $14.44 \mathrm{a}$ & $11.74 \mathrm{a}$ & $17.79 \mathrm{a}$ & - & $73.32 \mathrm{a}$ \\
\hline$P>F$ & 0.1319 & 0.1898 & 0.0206 & 0.7908 & 0.6214 & 0.6861 & 0.3333 & $\ldots$ & 0.8026 \\
\hline
\end{tabular}

${ }^{\mathrm{z}}$ Actinovate AG's active ingredient is Streptomyces lydicus and is produced by Natural Industries. Actinovate was applied as a foliar spray to watermelon plants 2 weeks after seeding at $0.011 \mathrm{~g}$ per $12.2 \mathrm{ml}$ of $\mathrm{H}_{2} \mathrm{O}$ per $0.156-\mathrm{m}^{2}$ transplant tray and again a week prior to transplanting to the field as a soil drench around the base of the plant at $0.115 \mathrm{~g}$ per $172 \mathrm{ml}$ of $\mathrm{H}_{2} \mathrm{O}$ per $1.89 \mathrm{~m}^{2}$ per plant. Means in a column followed by the same letter are not significantly different at $\alpha=0.05$ according to Fisher's protected least significant difference test. Statistical analysis was conducted using the Statistical Analysis System MIXED procedure; - indicates that the measurement was not taken for that date and location; AUDPC $=$ area under the disease progress curve. 
The extent of the disease suppression by $T$. incarnatum was comparable with that of $V$. villosa at UM-LESREC in 2011 but was lower at UD-REC in 2011. However, T. incarnatum significantly improved marketable watermelon yield compared with all other amended and nonamended plots at UM-LESREC in 2011, whereas $V$. villosa did not. The results of our trials, in terms of wilt severity and yield, indicate that $T$. incarnatum can be considered a viable alternative to $V$. villosa for management of Fusarium wilt of watermelon. The use of $V$. villosa as a green manure to suppress Fusarium wilt of watermelon has not been widely adopted because growers perceive that the seed may overwinter to become a weed (15). Growers might favor T. incarnatum over $V$. villosa because $T$. incarnatum does not reseed as proficiently in the mid-Atlantic region (38). Additionally, T. incarnatum does not vine and is less likely than $V$. villosa to outcompete future cash crops. It is possible that some growers might consider reseeding in fall an advantageous cover crop characteristic, because it reduces costs of planting and seed (11).

The magnitude of $V$. villosa's effects on disease and yield was dependent upon the severity of Fusarium wilt in the field. We did not observe significant cover crop disease-suppressive effects for the field trials conducted in locations with low Fusarium wilt severity. This also occurred in a study conducted in South Carolina, which examined the effects of $V$. villosa on Fusarium wilt of watermelon (16). However, although Fusarium wilt incidence at USDABARC was too low to detect significant green manure treatment effects on Fusarium wilt or yield, V. villosa and T. incarnatum green manures showed a notable, if insignificant, increase in marketable yield for the 2009 field season and a small, nonsignificant reduction in disease for both 2009 and 2010.

Although V. villosa and T. incarnatum green manures suppressed Fusarium wilt of watermelon on the eastern shore of Maryland and in Delaware, their ability to suppress disease needs to be evaluated under different climates and soil conditions where Fusarium wilt of watermelon is also severe. The variation in Fusarium wilt disease pressure observed in our experiments may have resulted, in part, from differences in the soil environment. Fusarium wilt of watermelon is most prevalent in sandy, slightly acidic soils ( $\mathrm{pH} 5$ to 6;
48). The field at USDA-BARC had a higher amount of organic matter and a more neutral $\mathrm{pH}$ compared with fields located on the eastern shore of Maryland and Delaware, which are very sandy, low in organic matter $(>1 \%)$, and have low $\mathrm{pH}$ levels. These environmental differences likely contribute to the prevalence of Fusarium wilt of watermelon on the eastern shore of Maryland and Delaware and partially explain why it is less common in central Maryland (44).

In our field trials, B. juncea-amended plots increased Fusarium wilt severity in three locations. Although these differences were not always significant, Fusarium wilt severity of watermelon in $B$. juncea-amended plots was never significantly lower than in bare ground plots. The results of our study are similar to the 2011 results of Mazzola et al. (26), who saw an increase in Fusarium spp. populations in the soil following brassica seed meal amendments. In vitro assays demonstrated that the isothiocyanate Benzyl ITC present in Brassica spp. increased sporulation of F. oxysporum isolate $9051 \mathrm{C}(33)$. There were observed elevations in $F$. oxysporum spp. populations in watermelon fields following the incorporation of B. juncea (28). In the same study, for one field season, Fusarium wilt of watermelon in B. juncea-amended plots had $10 \%$ more disease than plants in control (bare ground) plots (28). The effects of the secondary compounds of brassica cover crops have been extensively documented for other pathosystems $(20,26)$ but further research on the direct and indirect effects of Brassica spp. on $F$. oxysporum f. sp. niveum would help elucidate $B$. juncea's association with increased Fusarium wilt of watermelon.

Actinovate biocontrol resulted in either minimal or inconsistent reductions in Fusarium wilt of watermelon. In addition, we saw no benefit in the combination of the green manures and Actinovate biocontrol treatment on the suppression of Fusarium wilt. This is similar to results in other pathosystems, where Actinovate did not suppress disease. For example, Actinovate treatment did not reduce anthracnose (Colletotrichum obiculare) incidence or defoliation in watermelon, corm rot ( $F$. oxysporum f. sp. gladioli) of gladiolus (Gladiolus $\times$ hortulanus), Fusarium wilt incidence on tomato $(F$. oxysporum f. sp. lycopersici), or Fusarium root rot (Fusarium spp.) of sweet potato (Ipomoea batatas) $(6,8,9,13,37)$. However, Actino-

Table 5. Effects of tilled cover crop and Actinovate AG biocontrol application on marketable watermelon yield (number/hectare) at the University of Maryland's Lower Eastern Shore Research and Education Center (UM-LESREC), the United States Department of Agriculture at the Beltsville Agricultural Research Center (USDA-BARC), and University of Delaware's Carvel Research and Education Center (UD-REC) in 2009, 2010, and 2011

\begin{tabular}{|c|c|c|c|c|c|c|}
\hline Treatment $^{\mathrm{z}}$ & $\begin{array}{c}\text { UM-LESREC } \\
2009\end{array}$ & $\begin{array}{c}\text { UM-LESREC } \\
2010\end{array}$ & $\begin{array}{c}\text { UM-LESREC } \\
2011\end{array}$ & $\begin{array}{c}\text { USDA-BARC } \\
2009\end{array}$ & $\begin{array}{c}\text { USDA-BARC } \\
2010\end{array}$ & $\begin{array}{c}\text { UD-REC } \\
2011\end{array}$ \\
\hline \multicolumn{7}{|l|}{ Cover crop } \\
\hline V. villosa & $8,353 \mathrm{a}$ & $6,261 \mathrm{a}$ & $1,416 \mathrm{~b}$ & $12,333 \mathrm{a}$ & $7,400 \mathrm{a}$ & 6,159 a \\
\hline T. incarnatum & - & - & $2,883 \mathrm{a}$ & $12,223 \mathrm{a}$ & $6,355 \mathrm{a}$ & $6,745 \mathrm{a}$ \\
\hline S. cereale & $8,073 \mathrm{a}$ & $8,120 \mathrm{a}$ & $1,089 \mathrm{~b}$ & $11,417 \mathrm{a}$ & $7,736 \mathrm{a}$ & $7,486 \mathrm{a}$ \\
\hline B. juncea & - & $7,074 \mathrm{a}$ & $815 \mathrm{~b}$ & - & $6,840 \mathrm{a}$ & $6,536 \mathrm{a}$ \\
\hline Bare ground & $8,324 \mathrm{a}$ & $7,427 \mathrm{a}$ & $1,253 \mathrm{~b}$ & $11,110 \mathrm{a}$ & $8,598 \mathrm{a}$ & $6,572 \mathrm{a}$ \\
\hline$P<F$ & 0.2917 & 0.2247 & 0.0018 & 0.3417 & 0.5514 & 0.9323 \\
\hline \multicolumn{7}{|l|}{ Inoculation } \\
\hline No treatment & 8,259 a & _- & _- & $11,750 \mathrm{ab}$ & $7,310 \mathrm{a}$ & _- \\
\hline FON & $8,180 \mathrm{a}$ & $7,850 \mathrm{a}$ & $1,024 \mathrm{~b}$ & $11,147 \mathrm{~b}$ & $7,714 \mathrm{a}$ & $7,032 \mathrm{a}$ \\
\hline Actinovate + FON & $8,317 \mathrm{a}$ & $6,611 \mathrm{a}$ & $1,957 \mathrm{a}$ & $12,416 \mathrm{a}$ & $7,131 \mathrm{a}$ & $6,374 \mathrm{a}$ \\
\hline$P<F$ & 0.6834 & 0.0549 & 0.0033 & 0.0080 & 0.7392 & 0.4863 \\
\hline
\end{tabular}

${ }^{y}$ Marketable watermelon yield is the mean number of watermelon fruit per hectare that weighed more than $3.18 \mathrm{~kg}$. 'Sugar Heart' watermelon was used for all field trials. Means in a column followed by the same letter are not significantly different at $\alpha=0.05$ according to Fisher's protected least significant difference test. Statistical analysis was conducted using the Statistical Analysis System MIXED procedure; - indicates the absence of the specific cover crop treatment for the given time and location or that there was a loss in sufficient replications.

${ }^{\mathrm{z}}$ Cover crop seeding rates at UM-LESREC and UD-REC were Vicia villosa at $50.44 \mathrm{~kg} / \mathrm{ha}$, Trifolium incarnatum at $11.21 \mathrm{~kg} / \mathrm{ha}$, Secale cereale at $125.54-$ $134.50 \mathrm{~kg} / \mathrm{ha}$, and Brassica juncea at $11.21 \mathrm{~kg} / \mathrm{ha}$; and, at USDA-BARC, the seeding rates were V. villosa at $44.83 \mathrm{~kg} / \mathrm{ha}, T$. incarnatum at $28.02 \mathrm{~kg} / \mathrm{ha}, S$. cereale at $134.50 \mathrm{~kg} / \mathrm{ha}$, and B. juncea at $6.73 \mathrm{~kg} / \mathrm{ha}$. For the inoculation treatment, Actinovate AG's active ingredient is Streptomyces lydicus and is produced by Natural Industries. Actinovate was applied as a foliar spray to watermelon plants 2 weeks after seeding at a rate of $0.011 \mathrm{~g}$ per $12.2 \mathrm{ml}$ of $\mathrm{H}_{2} \mathrm{O}$ per $0.156-\mathrm{m}^{2}$ transplant tray and again a week prior to transplanting to the field as a soil drench around the base of the plant at $0.115 \mathrm{~g}$ per $172 \mathrm{ml}$ of $\mathrm{H}_{2} \mathrm{O}$ per $1.89 \mathrm{~m}^{2}$ per plant. Fusarium oxysporum f. sp. niveum (FON) was inoculated in 2009 at USDA-BARC and UM-LESREC at $6 \mathrm{ml}$ of $2.45 \times 10^{6} \mathrm{CFU} / \mathrm{ml}$ by pipetting into a hole (approximately $3 \mathrm{~cm}$ in diameter and $8 \mathrm{~cm}$ deep) $7 \mathrm{~cm}$ away from the crown of each watermelon plant immediately after watermelon transplanting. In 2010 at USDA-BARC, 2 days after cover crop incorporation and a week prior to the laying of black plastic, $60 \mathrm{ml}$ of $F$. oxysporum f. sp. niveum inoculum at $2.85 \times 10^{8} \mathrm{CFU} / \mathrm{ml}$ was mixed into 3.8 liters of $\mathrm{H}_{2} \mathrm{O}$ and evenly banded across the center of each $36.92-\mathrm{m}^{2}$ bed (into which watermelon would later be transplanted) with a watering can. In addition, $11 \mathrm{ml}$ of $F$. oxysporum $\mathrm{f}$. sp. niveum at $2.33 \times 10^{6} \mathrm{CFU} / \mathrm{ml}$ was added next to each watermelon plant using the same method employed in 2009. Fields used at UM-LESREC in 2010 and 2011 and UD-REC in 2011 were naturally infested. 
vate did reduce Fusarium surface rot of sweet potato and dollar spot of Bermuda grass $(13,35)$.

In the trials reported in this article, Actinovate negatively impacted vine length at one location, improved marketable watermelon yield in two of the six field trials, and decreased marketable watermelon yield in one of the six field trials. Other studies that tested Actinovate's growth- and yield-promoting abilities found similar results. Biomass of spinach treated with Actinovate AG + Micro 108 Seed Inoculant was no different than spinach in control plots (5). Tomato treated with Actinovate had yields that were no different than that of control plots (37). Actinovate SP + Latron BI956 treatments did not significantly impact watermelon yield (6).

The mechanism of Actinovate disease suppression has been linked with the ability of its active ingredient, S. lydicus, to colonize crop roots $(34,40)$. We were unable to isolate $S$. lydicus from the watermelon plant roots despite repeated attempts. Streptomyces spp. are favored by high $\mathrm{pH}$ and temperatures near $25^{\circ} \mathrm{C}$, and they are able to utilize complex organic materials as an energy source. S. lydicus activity is enhanced by high levels of soil organic matter $(14,18)$. The low levels of soil $\mathrm{pH}$ and organic matter on the eastern shore of Maryland and in Delaware could have inhibited S. lydicus growth, preventing the colonization of watermelon roots. Studies where Actinovate effectively reduced disease examined foliar pathogens or postharvest disease $(13,35,41)$. S. lydicus may be a more competitive antagonist in the phyllosphere than in the rhizosphere. Due to the nominal and inconsistent effects of Actinovate on Fusarium wilt of watermelon in this study, we do not recommend it for use against $F$. oxysporum f. sp. niveum. Actinovate did not have any additive effects on Fusarium wilt in combination with any of the cover crop treatments.

Both $V$. villosa and T. incarnatum suppressed Fusarium wilt of watermelon but the extent of the suppression was dependent on the magnitude of Fusarium wilt severity. The yield and soil health benefits of $T$. incarnatum are similar to that of $V$. villosa but $T$. incarnatum is also killed more easily and is less likely to overwinter under mid-Atlantic conditions.

Although the addition of Actinovate did not further reduce Fusarium wilt in this study, the combination of V. villosa or T. incarnatum green manures with other biocontrol products whose ability to colonize the watermelon rhizosphere and suppress Fusarium wilt of watermelon are already established could provide improved management of Fusarium wilt.

\section{Acknowledgments}

We thank D. K. Armentrout and M. E. Hochmuth for technical assistance at UM-LESREC; G. Myer and T. Currier for watermelon production assistance at USDA-BARC; B. Hearn for assistance with watermelon production at UD-REC; Y. Balci for material help, advice on experimental design, and review of the text; and Natural Industries for providing samples of the Actinovate biocontrol product.

\section{Literature Cited}

1. Candole, B. L., and Rothrock, C. S. 1998. Using marked strains to assess the effect of hairy vetch amendment on the inoculum densities of Thielaviopsis basicola, Pythium ultimum and Rhizoctonia solani. Soil Biol. Biochem. 30:443-448.

2. Clark, A., ed. 2001. Managing Cover Crops Profitably, 3rd ed. Handbook Series Book 9. Sustainable Agriculture Network, Beltsville, MD.

3. Corbett, C. J., and Pan, J. N. 2002. Evaluating environmental performance using statistical process control techniques. Eur. J. Oper. Res. 139:68-83.

4. Coumans, J. V. F., Moens, P. D. J., Poljak, A., Al-Jaaidi, S., Pereg, L., and Raftery, M. J. 2010. Plant-extract-induced changes in the proteome of the soil-borne pathogenic fungus Thielaviopsis basicola. Proteomics 10:15731591.

5. Cummings, J. A., du Toit, L. J., and Miles, C. A. 2008. Evaluation of seed and drench treatments for organic management of soilborne diseases of spinach in Sequim, WA, 2007. Plant Dis. Manage. Rep. 2:V133. Online publication. doi:10.1094/PDMR02

6. Damicone, J. P., and Pierce, L. R. 2006. Evaluation of fungicides for control of watermelon anthracnose, 2006. 1:V036. Plant Dis. Manage. Rep. Online publication. doi:10.1094/PDMR01

7. Dhananjeyan, V., Selvan, N., and Dhanapal, K. 2010. Isolation, characterization, screening and antibiotic sensitivity of Actinomycetes from locally (near MCAS) collected soil samples. J. Biol. Sci. 10:514-519.
8. Elmer, W. H., Elliott, G. 2000. The influence of microbial inoculants on Fusarium corm rot of gladiolus, 2000. Biol. Cult. Tests Control Plant Dis. Rep. 16:O42. Online publication. doi:10.1094/BC16

9. Elmer, W. H, and McGovern, R. J. 2004. Efficacy of integrating biological with fungicides for the suppression of Fusarium wilt of cyclamen. Crop Prot. 23:909-914.

10. Entry, J. A., Strasbaugh, C. A., and Sojka, R. E. 2000. Wood chip-polyacrylamide medium for biocontrol bacteria decreases Verticillium dahliae infection on potato. Biocontrol Sci. Technol. 10:677-686.

11. Evers, G. W., and Smith, G. R. 2006. Crimson clover seed production and volunteer reseeding at various grazing termination dates. Agron. J. 98:14101415. Online publication. doi:10.2134/agronj2006.0084

12. Ferguson, W., and Yee, J. 1997. Phasing out registered pesticide uses as an alternative to total bans: a case study of methyl bromide. J. Agribus. 15:6984.

13. Henn, A., and Burdine, A., 2010. Management of Fusarium surface rot of sweetpotatoes after packing in Mississippi, 2009. Plant Dis. Manage. Rep. 4:V109. Online publication. doi:10.1094/PDMR04

14. Hiltunen, L. H., Ojanperä, T., Kortemaa, H., Richter, E. Lehtonen, M. J., and Valkonen, J. P. T. 2009. Interactions and biocontrol of pathogenic Streptomyces strains co-occurring in potato scab lesions. J. Appl. Microbiol. 106:199-212

15. Jacobsen, K. L., Gallagher, R. S., Burnham, M., Bradley, B. B., Larson, Z. M., Walker, C. W., and Watson, J. E. 2010. Mitigation of seed germination impediments in hairy vetch. Agron. J. 102:1346-1351. Online publication. doi:10.2134/agronj2010.0002n

16. Keinath, A. P., Hassell, R. L., Everts, K. L., and Zhou, X.-G. 2010. Cover crops of hybrid common vetch reduce Fusarium wilt of seedless watermelon in the eastern United States. Plant Health Progress. Online publication. doi:110.1094/PHP-2010-0914-01-RS

17. King, S. R., Davis, A. R., Liu, W., and Levi, A. 2008. Grafting for disease resistance. HortScience 43:1673-1676.

18. Kinkel, L. L., Schlatter, D. C., Bakker, M. G., and Arenz, B. E. 2012. Streptomyces competition and co-evolution in relation to plant disease suppression. Res. Microbiol. 163:490-499.

19. Komada, H. 1975. Development of a selective medium for quantitative isolation of Fusarium oxysporum from natural soil. Rev. Plant Prot. Res. 8:115-125.

20. Larkin, R. P., and Griffin, T. S. 2007. Control of soilborne potato diseases using Brassica green manures. Crop Prot. 26:1067-1077.

21. Lewis, J. A., and Papavizas, G. C. 1977. Effect of plant residues on chlamydospore germination of Fusarium solani f. sp. phaseoli and on Fusarium root rot of beans. Phytopathology 67:925-929.

22. Ling, G., Huang, Q., Guo, S., and Shen, Q. 2011. Paenibacillus polymyxa SQR-21 systematically affects root exudates of watermelon to decrease the conidial germination of Fusarium oxysporum f. sp. niveum. Plant Soil 341:1485-493.

23. Ling, N., Xue, C., Huang, Q., Yang, X., Xu, Y., and Shen, Q. 2010. Development of a mode of application of bioorganic fertilizer for improving the biocontrol efficacy to Fusarium wilt. Biocontrol 55:673-683.

24. Littell, R. C., Henry, P. R., and Ammerman, C. B. 1998. Statistical analysis of repeated measures data using SAS procedures. J. Anim. Sci. 76:12161231.

25. Lucier, G., and Biing-Hwan, L. 2001. Factors affecting watermelon consumption in the United States. Veg. Specialties Situation Outlook 287:2329.

26. Mazzola, M., Granatstein, D. M., Elfving, D. C., and Mullinix, M. K. 2001. Suppression of specific apple root pathogens by Brassica napus seed meal amendment regardless of glucosinolate content. Phytopathology 91:673679 .

27. Netzer, D. 1976. Physiological races and soil population level of Fusarium wilt of watermelon. Phytoparasitica 4:131-136.

28. Njoroge, S. M. C., Riley, M. B., and Keinath, A. P. 2008. Effect of incorporation of Brassica spp. residues on population densities of soilborne microorganisms and on damping-off and Fusarium wilt of watermelon. Plant Dis. 92:287-294.

29. Ochiai, N., Powelson, M. L., Crowe, F. J., and Dick, R. P. 2008. Green manure effects on soil quality in relation to suppression of Verticillium wilt of potatoes. Biol. Fertil. Soils 44:1013-1023.

30. Payton, M. E., Richeter, S. J., Giles, K. L., and Royer, T. A. 2006. Transformations of count data for tests of interaction in factorial and split-plot experiments. BioOne 99:1002-1006.

31. Pruett, S. B., Myers, P. L., and Keil, D. E. 2001. Toxicology of metam sodium. J. Toxicol. Environ. Health Part B: Crit. Rev. 4:207-222. Online publication.

32. Rangappa, M., Hamama, A. A., and Bhardwai, H. L. 2002. Legume and grass cover crops for seedless watermelon production. HortTechnology 12:245-249.

33. Smolinska, U., Morra, M. J., Knudsen, G. R., and James, R. L. 2003. Isothiocyanates produced by Brassicaceae species as inhibitors of Fusarium ox ysporum. Plant Dis. 87:407-412.

34. Tokala, R. K., Strap, J. L., Jung, C. M., Crawford, D. L., Salove, M. H., Deobald, L. A., Bailey, J. F., and Morra, M. J. 2002. Novel plant-microbe rhizosphere interaction involving Streptomyces lydicus WYEC108 and the 
pea plant (Pisum sativum). Appl. Environ. Microbiol. 68:2161-2171.

35. Tomaso-Peterson, M., and Perry, D. H. 2007. The role of biofungicides and organic fertilizer in the management of dollar spot in bermudagrass. Appl. Turfgrass Sci. Online publication. doi:10.1094/ATS-2007-0911-01-RS

36. United States Department of Agriculture (USDA) /Economic Research Service (ERS). 2011. Fresh watermelon: U.S. imports by country, 19782010. USDA Economics, Statistics, and Market Information System. http://usda.mannlib.cornell.edu

37. Vallad, G. E., and Huang, C.-H. 2011. Evaluation of biopesticides and fungicides for management of Fusarium wilt and southern blight on tomato, 2010. Plant Dis. Manage. Rep. 5:V064. Online publication. doi:10.1094/ PDMR05

38. Williams, W. A., and Elliott, J. R. 1960. Ecological significance of seed coat impermeability to moisture in crimson, subterranean, and rose clovers in a Mediterranean type climate. Ecology 41:785-790.

39. Wu, H.-S., Yang, X.-N., Fan, J.-Q., Miao, W.-G., Ling, N., Xu, Y.-C., Huang, Q.-W., and Shen, Q. 2009. Suppression of Fusarium wilt of watermelon by a bio-organic fertilizer containing combinations of antagonistic microorganisms. Biocontrol 54:287-300.

40. Yuan, M. W., and Crawford, D. L. 1995. Characterization of Streptomyces lydicus WYEC108 as a potential biocontrol agent against fungal root and seed rots. Appl. Environ. Microbiol. 61:3119-3128.

41. Zhang, S. 2011. Evaluation of microbial products for management of pow- dery mildew on summer squash and cantaloupe in Florida. Plant Dis. 95:461-468.

42. Zhang, S., Raza, W., Yang, X., Hu, J., Huang, Q., Xu, Y., Liu, X., Ran, W., and Shen, Q. 2008. Control of Fusarium wilt disease of cucumber plants with the application of a bioorganic fertilizer. Biol. Fertil. Soils 44:10731080. Online publication. doi:10.1007/s00374-008-0296-0

43. Zhou, X. G., and Everts, K. L. 2003. Carryover effect of hairy vetch and urea soil amendments on Fusarium wilt of watermelon in the following year, 2003. B\&C Tests 19:V006. Online publication. doi:10.1094/FN58

44. Zhou, X. G., and Everts, K. L. 2003. Races and inoculum density of Fusarium oxysporum f. sp. niveum in commercial watermelon fields in Maryland and Delaware. Plant Dis. 87:692-698.

45. Zhou X. G., and Everts, K. L. 2004. Suppression of Fusarium wilt of watermelon by soil amendment with hairy vetch. Plant Dis. 88:1357-1365.

46. Zhou, X. G., and Everts, K. L. 2006. Suppression of Fusarium wilt of watermelon enhanced by hairy vetch green manure and partial cultivar resistance. Plant Health Progress. Online publication. doi:110.1094/PHP2006-0405-01-RS

47. Zhou, X. G., and Everts, K. L., 2007. Effects of host resistance and inoculum density on the suppression of Fusarium wilt of watermelon induced by hairy vetch. Plant Dis. 91:92-96.

48. Zitter, T. A., Hopkins, D. L., and Thomas, C. E. 1996. Compendium of Cucurbit Diseases. American Phytopathological Society, St. Paul, MN. 